The Autobiography

of a Seventeenth-Century

Venetian Rabbi 


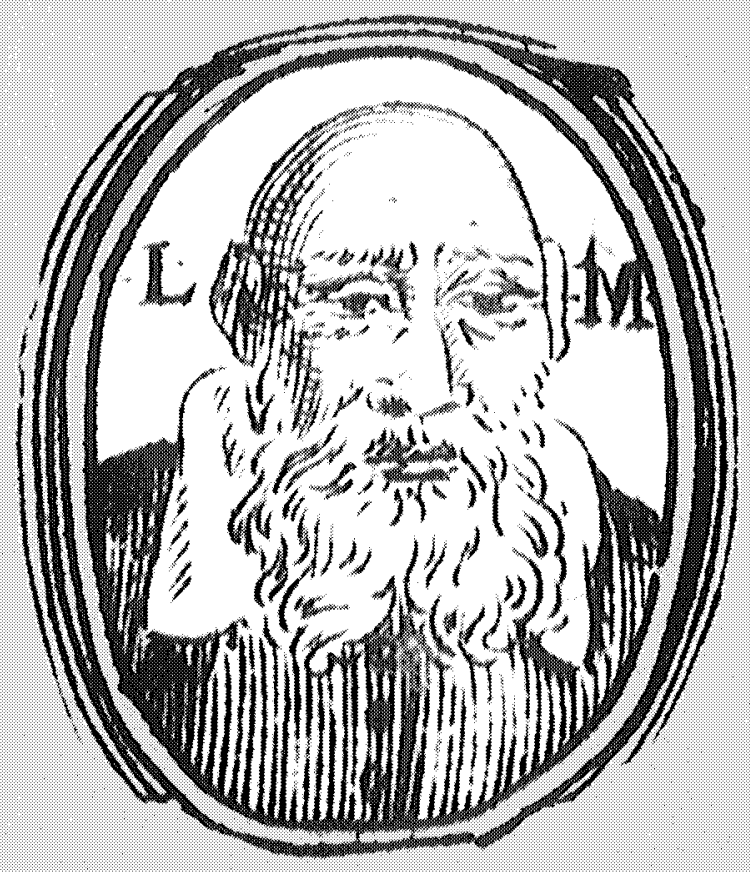




\section{The Autobiography of a}

Seventeenth-Century

\section{Venetian Rabbi}

\section{Leon Modena's}

Life of Judah

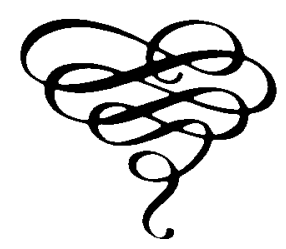

TRANSLATED AND EDITED BY

Mark R. Cohen

WITH INTRODUCTORY ESSAYS BY

Mark R. Cohen and Theodore K. Rabb,

Howard E. Adelman, and

Natalie Zemon Davis

AND HISTORICAL NOTES BY

Howard E. Adelman and

Benjamin C. I. Ravid

Princeton University Press

Princeton, New Jersey 
Copyright $\mathrm{C} 1988$ by Princeton University Press

Published by Princeton University Press, 4 I William Street,

Princeton, New Jersey o8540

In the United Kingdom: Princeton University Press,

Chichester, West Sussex

All Rights Reserved

Second printing, 1989

Library of Congress Cataloging-in-Publication Data

Modena, Leone, I $571-1648$

The autobiography of a seventecnth-century Venetian rabbi.

Translation of: Haye Yehudah.

Bibliography: $p$.

Includes index.

I. Modena, Leone, I 57I-1648. 2. Rabbis-Italy-Venice-

Biography. 3. Venice (Italy)-Biography. 4. Jews-ItalyVenice-History. 5. Venice (Italy)-Ethnic relations. I, Cohen,

Mark R., I943- . II. Title. III. Title: Leon Modena's Life of Judah. IV. Title: Life of Judah.

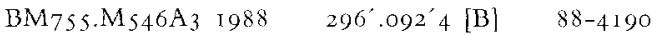

ISBN 0-69 I-05529-7 ISBN 0-691-00824-8 (pbk.)

Publication of this book has been aided by the Whitney Darrow Fund of Princeton University Press

This book has been composed in Linotron Bembo type

Princeton University Press books are printed on acid-free paper and meet the guidelines for permanence and durability of the

Committec on Production Guidelines for Book Longevity of the

Council on Library Resources

Printed in the United States of Amorica

Frontispiece: Portrait of Leon Modena, detail enlarged from the title page of the 1638 Venice edition of his Historia de'riti hebraici.

JACKeT AND Cover Illustration: Leon Modena's portrait, with the Rialto Bridge in Venice in the background. 
To Hanan and Tamar

and to the students in

History/Near Eastern Studies 442

"I thought that it would be of value to . . the fruit of my loins, and to their descendants, and to my students . .." -from The Life of Judah 
